\title{
Logika Backup dan Restore data pada Delphi
}

\author{
CHARZON \\ 165100040
}

Fakultas Komputer, 448757249

Charzon.student@umitra.ac.id

Backup data digunakan untuk membackup data yang telah kita inputkan pada program yang kita buat nantinya, supaya data yang kita inputkan tidak hilang atau ada file cadangannya. Sedangkan Restore data adalah mengembalika data yang dulu pernah kita simpan (Backup) untuk kita olah kembali

"Backup = file database yang akan kita backup akan dicopykan ke tempat lain (folder lain) sedangkan untuk Restore $=$ mengembalikan file database yang sudah dibackup ke tempat database aslinya dengan cara overwrite atau copy and replace."

Kata Kunci : Backup dan Restore data pada Delphi 


\section{A. INTRODUCTION}

\section{Logika Backup dan Restore data pada Delphi}

Langsung saja ikuti langkah-langkah berikut untuk membuat fitur Backup dan Restore data pada aplikasi yang akan kalian buat!

1. Pertama, siapkan terlebih dulu komponen Savedialog dan Opendialo g yang ada di menu Dialog.

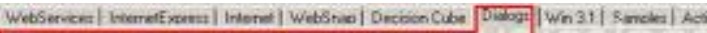

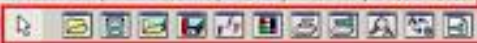

2. Siapkan juga button Backup dan Restore.

3. Pada button atau tombol Backup tambahkan source code di bawah ini:

var dir:string;

begin

dir:='C:Program Files\Catatan

Setterldatabases.mdb'; //sesuaikan dengan direktori database kalian if Application.MessageBox('Yakin untuk backup data ...?','Konfirmasi',MB_YESNO + MB_ICONQUESTION)= IDYES then Begin

SaveDialog1.FileName:='databases'; if SaveDialog1.Execute then begin if

FileExists(SaveDialog1.FileName) then begin
CopyFile(PChar(dir),PChar((SaveDial og1.FileName)),False);

Application.MessageBox('Database Sudah Dibackup','Informasi',mb_OK + mb_ICONINFORMATION);

end;

end;

end;

end;

4. Setelah tombol Backup selesai, tambahkan pula source code di bawah Ini pada tombol Restore:

var res:string;

begin

res:='C:|Program Files\Catatan

Setterldatabases.mdb';

if Application.MessageBox('Yakin untuk restore data

...?','Konfirmasi',MB_YESNO + MB_ICONQUESTION)= IDYES then Begin

if opendialog 1.execute then begin

if FileExists(opendialog1.FileName)

then begin

CopyFile(PChar(opendialog1.FileNam e),PChar((res)),False);

Application.MessageBox('Database Sudah Direstore.'+chr(10)+"+

'Restart program dulu untuk mengembalikan data semula!','Informasi',mb_OK + mb_ICONINFORMATION); end;

end; 
end;

end;

5. Setelah selesai coba dulu dengan menjalankan

program Backup data.

Catatan: Pada fariabel dir dan res sesuaikan dengan letak dimana file database kalian disimpan.

\section{B. CONCLUSION}

Backup Data

Backup data merupakan salah satu kegiatan yang harus dilakukan oleh pengelola database untuk melakukan penyalinan sistem, data dan aplikasi. Backup data harus dilakukan untuk menjaga jangan sampai terjadi kerusakan sistem dari luar ataupun dari dalam sistem, yang disengaja atau pun tidak disengaja.

Restore Data

Restore adalah proses mengembalikan backup ke dalam sistem. Restore dilakukan untuk mengembalikan keadaan sistem kembali pada keadaan semula, keadaan terakhir pada saat operasional, sebelum terjadi kerusakan sistem. Pada proses ini akan dilakukan

pengembalian data baik struktur maupun isi dari database, secara teori proses ini adalah proses minimum pengembalian system tergantung dari waktu scheduling yang menjadi dasar proses backup, jika waktu scheduling dijadwalkan terlalu lama maka akan banyak data nya hilang.

\section{ACKNOWLEDGEMENT} University Of Indonesia University Of Mitra Indonesia Telkom University University Of Mellbourne Saitama University

\section{REFERENCE (Based APA)}

A. S. Putra And O. M. Febriani, "Knowledge Management Online Application In Pdam Lampung Province," In Prosiding International Conference On Information Technology And Business (Icitb), 2018, Pp. 181-187.

[2] A. S. Putra, O. M. Febriani, And B. Bachry, "Implementasi Genetic Fuzzy System Untuk Mengidentifikasi Hasil Curian Kendaraan Bermotor Di Polda Lampung," J. Sist. Inf. Dan Manaj. Basis Data, Vol. 1, No. 1, Pp. 21-30, 2018.

[3] O. M. Febriani And A. S. Putra, "Sistem Informasi Monitoring Inventori Barang Pada Balai 
Riset Standardisasi Industri Bandar Lampung," J. Inform., Vol. 13, No. 1, Pp. 90-98, 2014.

[4] Putra, Arie Setya. "2018 Artikel Struktur Data, Audit Dan Jaringan Komputer." (2018).

[5] Putra, A. S. (2018, July 17). Paperplain Fundamental Create Application With Borland Delphi 7.0 University Of Mitra Indonesia. Retrieved From Osf.Io/Pbrn9.

\section{E. REFERENCE (Based APA)}

Putra, A. S., Aryanti, D. R., \& Hartati, I. (2018, November). Metode SAW (Simple Additive Weighting) sebagai Sistem Pendukung Keputusan Guru Berprestasi (Studi Kasus: SMK Global Surya). In Prosiding Seminar Nasional Darmajaya (Vol. 1, No. 1, pp. 85-97).

Sari, D. P., Febriani, O. M., \& Putra, A. S. (2018, November). Perancangan Sistem Informasi SDM Berprestasi pada SD Global Surya. In Prosiding Seminar Nasional Darmajaya (Vol. 1, No. 1, pp. 289-294).

Putra, A. S. (2018). Paperplain: Execution Fundamental Create Application With Borland Delphi 7.0 University Of Mitra Indonesia.

Putra, A. S., Sukri, H., \& Zuhri, K. Sistem Monitoring Realtime Jaringan Irigasi Desa (JIDES) Dengan Konsep Jaringan Sensor Nirkabel. IJEIS (Indonesian Journal of Electronics and Instrumentation Systems), 8(2), 221232.
Darmawan, A., Yuliawati, D., Marcella, O., \& Firmandala, R. (2016). Sistem Absensi dan Pelaporan Berbasis Fingerprint dan SMS Gateway. EXPLORE, 7(1).

Febriani, O. M., Wahyuni, T., \& Yusuf, S. (2017). DESIGN OF WEBSITE-BASED INFORMATION SYSTEM FOR EDOCUMENT ADMINISTRASI IN THE COMMUNITY SERVICE UNIT (A Case Study at Rajabasa District). INTERNATIONAL JOURNAL OF COMPUTERS \& TECHNOLOGY, 16(7), 7010-7020.

Febriani, O. M., \& Wahyuni, T. (2017, October). PERANCANGAN SISTEM E-DOCUMENT ADMINISTRASI LOGBOOK PENELITIAN PADA UNIT LAYANAN DI BANDAR LAMPUNG. In Prosiding Seminar Nasional Darmajaya (Vol. 1, No. 1, pp. 187-194).

Febriani, O. M., \& Permadi, A. B. (2017). Implementasi Sistem Aplikasi Data Bimbingan dan Pelanggaran Siswa pada Sekolah Menengah Atas di Lampung Tengah dengan Metode Analisis dan Desain Sistem Terdistribusi (SSAD). EXPERT, 7(1).

Febriani, O. M., \& Ambarwati, L. (2015). PERANCANGAN APLIKASI PENGOLAHAN DATA PENJUALAN UKM KELANTING KHAS TELO DESA SIDOHARJO KECAMATAN JATI AGUNG KABUPATEN LAMPUNG SELATAN. Jurnal Teknologi Informasi dan Bisnis Pengabdian Masyarakat Darmajaya, 1(1), 77-95. 
Febriani, O. M. (2015). Rancang Bangun Aplikasi Ecommercemenggunakan Freewebstore pada UKM Kelanting di Desa Sidoharjo Lampung Selatan. Prosiding Sembistek 2014, 1(02), 446-458. 